\title{
New Geographies of Tourist Consumption: The Case of Montenegro
}

\author{
Sanja Pekovic \\ University of Montenegro, Montenegro \\ Jovana Vukcevic \\ University of Montenegro, Montenegro \\ Tatjana Stanovic \\ University of Montenegro, Montenegro \\ Djurdjica Perovic \\ University of Montenegro, Montenegro
}

\section{Abstract}

The aim of this paper is to increase the understanding of the opportunities and obstacles for developing entrepreneurial activities in agro-tourism sector in northern Montenegro. Therefore, this paper, thus, aims to set a framework for studying the role of innovations and entrepreneurship in the development of sustainable agro-tourism through identifying and providing suggestions for overcoming main entrepreneurial obstacles.

Keywords: entrepreneurship, rural development, katun activities, agro-tourism, Montenegro

JEL classification: L83, L26

\section{Introduction}

The paper aims at questioning the new patterns of agro-tourist production and consumption which are emerging in the region as rural households seek to diversify their agro-related activities and tourists continue to seek out new experiences, authentic destinations and innovative types of consumption in terms of food, place, leisure and entertainment. First part of the paper questions the intersection between tourism and agriculture, its potentials and implications for rural restructuring, sustainable territorial development and empowerment of local communities. The second part discusses entrepreneurial activities in rural areas and various emerging forms of agro-tourism, while the third emphasizes some of the main challenges and obstacles hampering the entrepreneurial development of this sector. In conclusion, we will synthesize our analysis and apply it to the Montenegrin case, analyzing the current activities and proposing several suggestions for overcoming obstacles and fostering entrepreneurial activity in Montenegrin agro-tourism sector.

\section{Methodology}

When exploring potentials of agro-tourism, entrepreneurial activities and their main obstacles and challenges, two regions were specifically targeted, the Kuči mountains and the Durmitor area. These two areas are specific due to their social aspect (e.g. richness of cultural heritage, customs related to the life in the katuns, architecture, etc.) and, especially in case of Durmitor, characterized by resources available for agricultural production and certain positive trends in development of agriculture (sheep and cattle rearing and production of specific dairy products, as 
well as new sectors of agriculture like growing potatoes, buckwheat, cereals, etc.). In addition, Durmitor represents the most visited and tourist exploited mountain in Montenegro, being widely recognized as the one of the most popular tourist destinations in the country. The Kuči mountains, due to landscape characteristics, are becoming very popular among the backpackers of all kinds, being situated in the nearest vicinity of the capital Podgorica and its transportation, infrastructure and logistic facilities. Having these two most typical areas employed as case studies, the research covers almost all the dominant aspects of rural life and agro-tourism entrepreneurship anywhere in Montenegro, as well as the major categories of their cultural heritage's protection and preservation.

\section{Results}

In the explored regions, it was evident that agro-tourist offer was extremely limited, and mostly based on offer of food and beverage. Specialized producers of typical regional products (wines, brandy, prosciuttos ham, olive oils, honey, berries etc.) are either non-aware of the possibilities to grow their business by incorporating tourism into their agricultural endeavors, or consider it to be too costly, too complicated and out-of-scope. Therefore, their activity mostly turns around traditional agricultural production and sale through roadside stands or directly to nearby restaurants and hotels. This is especially true for katuns, temporary settlements in mountainous regions where the agricultural households stay with livestock during the summer season. This distinctive Montenegrin tradition reflects the richness of cultural and historical identity of the mountain pastures and represents an exploitable tourist resource, allowing tourists to admire the picturesque countryside while tasting traditional agro-products of superior quality.

Katuns are not only attractive in terms of natural resources and heritage potential, but also specific architecture reflecting specific ethno-cultural characteristic, specific furniture and utilities (which should, however be arranged in accordance with minimum comfort requirements) and traditional tools used for decades in farming work, highlighting the ethnic originality and creativity. It is possible to arrange some of the katuns into gift shops selling organic products such as milk, cheese or meat, into mini-museums displaying traditional costumes, farming tools and objects; restaurants suggesting traditional dishes made of locally-manufactured organic products, etc.

When discussing possible entrepreneurial activities in these areas it is necessary to take into consideration not only the geographical position, natural potentials, local community and available infrastructure, but also the socio-demographic character and specific ethno-cultural features influencing the feasibility of the suggested solutions. In reference to all of these, some of the suggested diversification activities might include transit tourism/short breaks between 4-8 days duration (e.g. Bed \& Breakfast/Bed \& Bike, excursions); active tourism (e.g. hiking, biking); eco-agro tourism (e.g. organic farms, flora \& fauna watching); events (e.g. local music and folklore events, celebrations); MICE (e.g. team building); gastro-tourism (e.g. cheese production, cooking, harvest, fishing); educational or scientific or volunteer agrotourism (e.g. dry stone workshop, organic farming); cultural (e.g. gastronomy, handcraft, souvenirs) and mixed forms (e.g. katun network).

Several successful entrepreneurial ventures created attractive agro-tourist offer at katuns (Stara Kuca in Kucka Korita, eco-katun Stavna Andrijevica, Vranjak in Kolasin), and some even used digital innovation to promote sustainable lifestyle, nature and gastronomy of the region. American entrepreneur Brit Boone created Meanderbug, a successful platform connecting local hosts and tourists willing to stay in katuns and 
village cottages, explore the agro-products or natural landscapes and immerse with traditional production, mountain sports or local culture. In an interview conducted in June 2016, Brit Boone highlighted that, according to his experience, the hosts from northern Montenegrin countryside are in general knowledgeable about the village life and attractions in the region, which allows them to provide useful recommendations to tourists. They have natural hospitality and cooking skills enabling unforgettable traditional gastro-experience. Yet, according to him, they in general lack the capacity to fix errors on-the-go, to comply with hospitality standards and to adapt their offer to tourists' requirements. This, along with the fact that only $3 \%$ of overnights is generated in central and north part of Montenegro, is why it would be so important to address issues preventing the stronger development of agro-tourism in northern Montenegro.

When addressing the obstacles to entrepreneurship in Montenegro, it is noteworthy that the communist system did not give the possibility for private ownership development (Aidis, 2005), due to which Montenegro only recently developed the environment suitable for innovation and entrepreneurship. Thus, the entrepreneurial culture is still on a relatively low level and not many households consider entrepreneurial agro-tourist ventures when planning and implementing their agricultural activities. Based on interviewers and observation, the development of agro-tourism in northern Montenegro has good growth potential, but it faces a number of obstacles:

1) Management capabilities are weak;

2) IT knowledge is limited;

3) Lack of funding for investment presents a major constraint;

4) Available infrastructure (e.g., internet access; transport) is deficient;

5) Government support is limited.

\section{Discussion}

Firstly, the weakness concerning management capabilities could be overcome by promoting partnerships between agro-tourism entrepreneurs and larger tourism organizations providing management and marketing services (Frazier and Niehm, 2004; Gaddefors, 2005). For instance, Beritelli (2011) and Go and Govers (2000) report the advantages of regional level tourism marketing cooperation. Moreover, Dimitrovski et al. (2012) indicate that tourist organizations play very important role in providing education of people involved in rural tourism. Additionally, obstacle associated to the lack of IT skills could be also eliminated by partnering with relevant organizations, and providing farmers relevant IT training (which should be organized and stimulated by the Government). Thirdly, as indicated by Schendel and Hitt, (2007) entrepreneurship in rural tourism could be helped by Governments by allocating resources to develop and commercialize their services. Moreover, additional trainings and seminars should be organized to present external funding that could be obtained (e.g. EU funding). Fourthly, Governments play the main role in providing the essential physical infrastructure for business, e.g. streets, roads, water systems, airports. Finally, as we discussed the importance of entrepreneurial activities for economic growth, government should be more involved in stimulating and creating an appropriate business environment for entrepreneurial development in agro-tourism business. More precisely, government should propose policies and programs that targeted specifically entrepreneurial activities in order to develop skills and capabilities necessary for starting and running businesses (Lordkipanidze et al., 2004). 


\section{Conclusion}

The transition from the exclusively product-based economy of rural areas into tourism entrepreneurship requires not only the set of financial instruments and capacity building tools, but also a significant change in prevailing rural mentality. This represents an important challenge for local communities in Montenegro, since creation of new opportunities can only be achieved through substantial involvement, training and education of farmers. The field research and interviews conducted in 2016 undoubtedly pointed out to the lack of entrepreneurial knowledge and hospitality awareness among the local communities in northern Montenegrin countryside. It would be of the outmost importance to raise the awareness in society, institutions, government and related authorities, of the importance of educating the local community with the entrepreneurial knowledge, as well as increasing the hospitality awareness, providing financial incentives, business infrastructure, developing public-private partnerships and fostering rural networking.

As discussed in previous sections, a successful entrepreneurial venture requires much more than a mere recognition of market potential, namely the capacity to invest time, effort and sources, to identify potential customers, sources of funding and commodity market for the service or product offered, to correctly evaluate business idea, costs, risks and opportunities (Pribeanu et al., 2014). In general, we can say that the obstacles restraining development of entrepreneurial activities in agrotourism constitute one complex structure, where the internal and external obstacles affect each other. It would be unrealistic to expect that the most farm households will have the necessary knowledge, skills and analytical tools to process and organize all these requests. Therefore, if Montenegro decides to strive towards sustainable tourism, it will have to start by providing incentives, training and support to the farmers eager to diversify their agro-activities through entrepreneurial actions. Noteworthy, the findings of this study could be useful for the design of public-support policies for this sector.

\section{References}

1. Aidis, R. (2005), "Entrepreneurship in transition countries: a review", Economics Working Papers 61, Centre for the Study of Economic and Social Change in Europe, SSEES, UCL, London, UK.

2. Beritelli, P. (2011), "Cooperation among prominent actors in a tourist destination", Annals of Tourism Research, Vol. 2, pp. 607-629.

3. Dimitrovski, D.D., Todorović, A.T., Valjarević, Dj. (2012), "Rural tourism and regional development: Case study of development of rural tourism in the region of Gruža, Serbia", Procedia Environmental Sciences, Vol. 14, pp. 288-297.

4. Frazier, B.J., Niehm, L.S. (2004), "Exploring business information networks of small retailers in rural communities", Journal of Developmental Entrepreneurship, Vol. 9, pp. 23-42.

5. Gaddefors, J. (2005), "Creating context - entrepreneurial opportunities in a consumer market setting", Journal of Enterprising Culture, Vol. 13, pp. 197-222.

6. Go, F.M., Govers, R. (2000) "Integrated quality management for tourist destinations: a European perspective on achieving competitiveness", Tourism Management, Vol. 21 pp. 79-88.

7. Lordkipanidze, D., Vekua, A., Ferring, R., Rightmire, G. P., Zollikofer, C. P.E., Ponce de León, M. S., Agusti, J., Kiladze, G., Mouskhelishvili, A., Nioradze, M., Tappen, M. (2006), "A fourth hominin skull from Dmanisi, Georgia", Anat. Rec., Vol. 288, pp. 1146-1157. 
8. Pribeanu, G., Toader, C.S., Sambotin, D. (2014), "Entrepreneurial Policis in Tourism and Agro-łourism", Lucrări științifice Management Agricol, Vol. 16 No. 4, pp. 77.

9. Schendel, D., Hitt, M. A. (2007), "Introduction to Volume 1", Strat. Entrepreneurship Journal, Vol. 1, pp. 1-6.

\section{About the authors}

Dr Sanja Pekovic has a Ph.D. in Economics from the University Paris-EST. She is Assistent Professor at the University of Montenegro. Between 2006 and 201 1, she was Researcher at the Center for Labor Studies (Centre d'Eudes de l'Emploi) and Lecturer at the University Paris-EST. In 2006, she obtained a Master's degree from the Ecole Nationale Des Pontset Chaussées and University of Paris-EST Marne-la-Vallée. Her research interests are within the field of quality and environmental economics, economics of innovation, applied econometrics, and on this topic she has published in international journals. Author can be contacted at psanja@ac.me.

Jovana Vukcevic is a teaching assistant at University of Montenegro and a predoctoral researcher at University of Bielefeld and Graduate School Global and Area Studies in Leipzig. She works as a consultant for empowerment of capacities for development of sustainable agro-tourism (Katun HERIC project Montenegro) and research fellow of the ZEIT-Stiftung's program "Trajectories of change" (Hamburg, Germany). She holds a Masters in European studies from EHESS Paris and Charles University Prague, as well as Masters in Economics from University of Nice. Jovana has been granted numerous scholarships and awards and she presented her research papers at academic conferences in Dublin, Paris, Berlin, Florence, Munich, Istanbul... Her research interests include sustainable heritage management, sociology of tourism, memory studies, entrepreneurship and urban development. Author can be contacted at jo.vukcevic@gmail.com.

Tatjana Stanovcic has a Ph.D. in Economics from the University of Belgrade. She is a Professor at the Faculty of Tourism and Hotel Management where she preformed the function of Dean since 2007 till 2013. Stanovcic participates in research projects developed jointly with other departments of University of Montenegro but also closely collaborates with other faculty in the region. Her main research interest focuses on the analysis of the financial and accounting indicators in tourism and hotel management, and on this topic she has presented studies at national and international scientific congresses, which have been published in international journals. Author can be contacted at stanja@ac.me.

Dr Djurdjica Perovic has a PhD from University of Novi Sad, with the Thesis. She is an Associate Professor at the Faculty of Tourism and Hotel Management. She presented and published several articles and congress papers within the field of tourism development, selective tourism, and sustainable development in tourism and hotel industry. She is a member of Editorial Board for number of journals. She has attended many courses and seminars related to geotourism, entrepreneurship, selective tourism, faculty development and e-learning. Author can be contacted at duda@ac.me. 